\title{
Women in the board room: one can make a difference
}

\section{Judith Lynne Zaichkowsky}

\author{
Beedie School of Business, \\ Simon Fraser University, \\ Vancouver, Canada \\ E-mail: zaichkow@sfu.ca
}

\begin{abstract}
This empirical study challenges the theory that a 'critical mass' of three or more women at the boardroom table is needed to make a difference. Performance ratings of Canadian publicly traded companies by the Globe and Mail show consistently higher corporate governance scores for companies with more women on their boards of directors. However, while companies that had three or more women on their boards had the highest scores, companies with only one woman on the board scored significantly higher than those with none. There was also no relationship between the number of women on boards of directors and Corporate Knights' social responsibility ratings on a national or global basis. The size of board and the type of industry are other important factors to consider when proposing quotas for female board members.
\end{abstract}

Keywords: board of directors; women on boards; corporate governance; social responsibility; compensation; industry; gender quotas; Canada.

Reference to this paper should be made as follows: Zaichkowsky, J.L. (2014) 'Women in the board room: one can make a difference', Int. J. Business Governance and Ethics, Vol. 9, No. 1, pp.91-113.

Biographical notes: Judith Lynne Zaichkowsky is a Professor of Marketing. She served a five-year term on the Board of Governors for SFU and became very interested in corporate governance. Her other research publications are in the field of involvement; trademark infringement and counterfeiting; and more recently aesthetic choice behaviour.

\section{Introduction}

There is ongoing discussion and debate outside and inside corporate boardrooms about diversity in management and representation of women on boards of publicly traded companies (e.g., Adams and Ferreira, 2009; Bart and McQueen, 2013; Strategic Direction, 2013). The importance of diversity in top management, especially gender equity, is thought to lead to better managed companies on a variety of dimensions (Bear et al., 2010). There is a push for representation quotas in many countries, including Canada, the USA, and the UK, which have white papers on the subject of quotas (Canadian Coalition, 2011; CED, 2012; Davis, 2011; Norris, 2012). Following the European Commission Directorate General for Justice (2012) report for representation of women, Germany agreed that supervisory boards be at least 30\% women by 2016 (The Economist, 2013). In March 2013, the Canadian Federal 
Government created a committee to help increase the representation of women on boards of directors (McFarland, 2013a). A short time later, the Ontario Teacher's Pension Plan submitted a proposal to the Ontario Securities Commission calling for delisting of companies that do not have at least three women on their boards by 2020 (McFarland, 2013b).

Recently, Morgan Stanley created an investment portfolio which features companies committed to promoting women on to corporate boards (Nelson, 2013). This portfolio will buy into companies which have at least three women on their boards. Their rationale is based on previous research that proposed that a company must have 'at least' three women in the boardroom to create a critical mass 'to make a difference' (e.g., Konrad et al., 2008; Torchia et al., 2011). The link between three or more women and 'making a difference' is difficult to test, because there has not been a good representation of companies which have more than three women on their boards. Recent studies have looked at the broader relationship of number of women on boards, as a percentage figure, and firm financial performance with positive results, inconclusive results, marginal results, or even negative results (e.g., Gregory-Smith et al., 2014; Luckerath-Rovers, 2013; O’Reilly and Main, 2012; Rose, 2007). Many of these studies find companies have, on average, less than one woman on the board (e.g., Rose, 2007). O'Reilly and Main (2012) found that boards with more women as outside directors were more generous in compensating the CEO.

Investors and customers are interested in the corporate governance and social responsibility of the companies. Women have been found to be more aware of their corporate responsibility (Bart and McQueen, 2013) and to be more benevolent and universally concerned, but less power-oriented (Adams and Funk, 2012). Therefore, women are thought to be a factor in bringing more effective governance and greater corporate social responsibility (CSR) to a company, which, in turn, may lead to a healthier and more sustainable company (Bear et al., 2010).

Since the Canadian Government and union groups are actively advocating that corporate companies increase their representation of women in the boardroom, a closer look at relevant data is warranted. This paper, therefore, poses the following research questions:

RQ1 Does having more women on the board of directors lead to more effective corporate governance?

RQ2 Does having more women on the board lead the company to be more socially responsible?

RQ3 Do companies with more women on their board award the CEO higher compensation?

These questions are important to investigate further to inform global legislative practices of gender 'quotas' in corporate governance and to establish investment portfolios based on the number of women directors. Thus, not only should those who control and govern companies and stock markets be interested in these questions, but also those who are interested in investing in funds which are based on companies having three or more women on the Board of Directors. 


\section{Literature review}

The investigation of women on boards of directors over the past two decades covers many facets of the issue. Early research by Daily et al. (1999) examined US data from 1987 to 1996; they found the average number of women on boards doubled during that time period. Data from the USA demonstrates that larger organisations, organisations which have more women employees, firms with an active diversification programme, and companies with networks to other women by the current board members, have more women directors (Hillman and Cannella, 2007). However, the factors which lead to more women on boards are not corroborated across western countries. Further, a study of Australia's top 100 companies, using similar variables and measures, found that only shareholder concentration contributed to diversity (Kang et al., 2007). Indeed, the presence of women at the board table varies drastically across countries $(0.2 \%$ in Japan to $22 \%$ in Slovenia), reflecting a cultural and value-based approach to the issue (Terjesen and Singh, 2008).

\subsection{The theory of the critical mass of three}

Group theory from the sociology and psychology literature has evolved into the literature about the effectiveness of women on boards of directors (e.g., Asch, 1955; Bond, 2005; Kanter, 1977a). Kanter (1977b) pioneered a study of the proportion of women in predominantly male groups and its relationship to social organisations, group processes, and male-female interactions in the context of industrial sales in 1974. In-depth interviews with 16 women in sales and distribution, interviews with 40 male peers, and observation of sales-training groups, formed the basis for testing theories related to skewed sex ratios and token women on group life. The different types of groups were identified as:

1 uniform, or one kind of person

2 skewed or token (85:15), where there is a large preponderance of one type over another

3 tilted (65:35), where minority members are allies and can affect the culture of the group; and finally

4 balanced (60:40-50:50).

The premise of the theory is that minorities feel they have a voice and are more comfortable in expressing themselves in a minority rather than a token situation. Two group members out of ten (20\%) were deemed not always enough to overcome tokenism status unless the tokens are highly identified with their own social category [Kanter, (1977b), p.987].

Kanter's theory about minority member allies forms the basis for many studies about the effectiveness of women in the boardroom (e.g., Joecks et al., 2013; Torchia et al., 2011). However, the premise that tokenism or feelings of isolation may not be at play when an individual highly identifies with their social category seems to have been overlooked or forgotten. Some previous qualitative studies do demonstrate the fit with the social category. For example, in-depth interviews with women directors of US traded 
companies revealed perceived increases in support and communication among women on boards when more women were present (Konrad et al., 2008). However, the authors concluded that "even one woman can make a positive contribution", although boards with three of more women benefited most from women's contributions [Konrad et al., (2008), p.160]. Women's contributions to the board circled around issues, such as asking difficult questions, demanding direct answers, countering win-lose discussions, and general improvement of decision-making in the board room.

A similar study by Lamkin Broome et al. (2011) found lone woman board members embrace being the first and perhaps only woman board member and are at ease with that role. They found no support for the theory that a critical mass of women directors achieved different and distinctly feminine board outcomes. In many cases the board role was perceived as gender neutral as exemplified by a quote from a male board chair to a new woman on the board: "You were wonderful to be here. We didn't even realize you were a woman” (p.1070).

Despite findings which support the voice of the lone woman at the boardroom table, the repeated, and now almost fact-like, comment within corporate recruiting firms, is that a board of directors must have at least three women at the table for the women to 'be heard' or 'add value' to the firm. This comment has been extrapolated to "with three women on board, the gender issue disappears" (Rhinehart et al., 2013).

Corporate governance. The connection between corporate governance and three or more women on boards are of interest because good governance is thought to be related to company performance. In the analyses of test scores of board directors for complex and moral reasoning, women were found to score higher than their male counterparts (Bart and McQueen, 2013). Reasoning is highly related to decision making and is hypothesised to be an important skill for making complex board decisions. Therefore, it is expected that women contribute highly to asking the right questions within the board room.

An investigation of the claim that three or more women are needed to have a voice heard at the board table was carried out in Norway with a survey questionnaire (Torchia et al., 2011). (Norway was thought to have the highest percent of companies having more than three women on their board, due to legislation). The dependent variables were the level of firm innovation and board strategic tasks. A total of 317 responses from CEOs of companies of boards, comprised of 6 to 12 people, found that boards with three or more women made it possible to enhance the level of the firm's innovation. Moreover the relationship between the critical mass of women directors and innovation is mediated by board strategic tasks. The researchers concluded that boards of directors need to have 'at least three women' to enable them to interact and influence board decisions, which in turn increases innovation.

CSR. Besides corporate governance, there is a body of research around the issues of number of women board directors and CSR (Bear et al., 2010; Huse et al., 2009). Using data from the USA healthcare industry, Bear et al. (2010) found CSR ratings, as measured by the KLD database, had a positive impact on reputation and mediated the relationship between the number of women on a board and corporate reputation as measured by the Fortune 2009 list of the world's most admired companies. KLD Research \& Analytics, Inc., situated in Boston, analyses and selects firms based on strengths and concerns in the following categories: products and services (e.g., ozone-depleting chemicals, agricultural chemicals); operations and management (recycling, management systems, hazardous waste, regulatory problems, substantial 
emissions); and climate change (clean energy, revenues from coal oil and derivative products).

Similar findings using survey data from Norway were not supported by Huse et al. (2009), leaving the debate open. In their study, CSR was measured by rating three items:

1 issues about health and safety

2 issues about the natural environment

3 issues related to charity.

Clearly, the two studies differed widely in how CSR was measured. Further, Bear et al. (2010) focused only on the healthcare sector, so there may even be differences due to types of industries.

Fernandez-Feijoo et al. (2012) looked explicitly at the effect of having three or more women on boards of directors and the links to CSR reporting. Their results were mixed in that they found companies increase the disclosure of CSR strategy when there were more than three women directors, but they issued more stand-alone reports rather than integrated ones. More than three women on the board was also a determinant of disclosure of supply-chain risk and of having an assurance statement. However, having three or more women did not affect the disclosure of business opportunities or financial value of CSR, nor did it relate to disclosure of carbon footprints in the country. No sample sizes were reported for the number of companies which have three or more women; therefore, the link between three or more board women and CSR warrants further quantitative analyses.

CEO compensation. A recent study by O'Reilly and Main (2012) used a sample of 2,000 US firms over the period 2001 to 2005 to investigate the relationship between women directors and firm performance and CEO compensation. The number of women directors ranged from zero to six (average .7), with $38 \%$ of the firms having no women directors. They found that male CEOs with higher levels of compensation are more likely to appoint women and those boards with more independent women directors are more generous in paying the CEO. The underlying innuendo here maybe that women are rewarding the CEOs for their place on the boards. Or women are more generous than their male counterparts.

\subsection{Summary}

Previous researchers found a positive relationship between more women board members and enhanced or more effective corporate governance. More diverse and better discussions around the board table are reported and are said to be due to the presence of women. However, the theory of critical mass, specifically 'three or more women,' to make a difference in corporate governance is challenged with qualitative studies which find a lone woman does not necessarily feel isolated and does not hesitate to be engaged or contribute to board discussions and activities.

The studies which surround the number of women on the board and increased CSR were also not definitive as the most positive findings were limited to the study of 51 firms in the healthcare industry (Bear et al., 2010). This research seeks to study these phenomena across industry sectors in Canada using widely published measures of corporate governance and CSR. Finally, the relationship between the number of women board members and CEO compensation in Canada is of interest. Canada is a much 
smaller country, in economic terms, with a vastly different make-up of publicly traded companies; hence there may be different results for CEO compensation.

\section{Methodology}

\subsection{The databases}

Canada's top publicly traded companies are examined regularly by various organisations on behalf of independent investors. Two unique databases were used for this study:

1 board games by the Globe and Mail $(G \& M)$ newspaper, the source for corporate governance scores

2 CSR ratings by Corporate Knights (CK) magazine.

The $G \& M$ is Canada's business newspaper and rates publicly traded companies on corporate excellence against a demanding set of criteria designed to go far beyond the minimum mandatory requirement imposed by regulators. $C K$, self-described as the 'Magazine for Clean Capitalism', is headquartered in New York, with offices in Toronto, and its mission is to identify the world's best socially responsible companies. Each year they publish national and international CSR ratings of companies.

Corporate governance scores. 'Board Games' has been published annually by the $G \& M$ since 2002. These are annual assessments of the governance practices of large public companies traded on the Toronto Stock Exchange (TSX). Each company is scored on a variety of criteria and then rated out of 100 based on best practices for boards. The specific questions and points awarded for governance categories have changed over the years as laws and issues around governance have changed and evolved. The total points of 100 for 2012 were derived from the following four factors: board composition (31 points); shareholding and compensation (26 points); shareholder rights (31 points); and disclosure (12 points). Examples of the factors and questions can be found in the Appendix and on the $G \& M$ website.

The first survey conducted in 2002 did not address the issue of women at the board table; hence, the analyses start in 2004. In 2004, companies were given one point for the presence of one woman on the board; if at least one-third of board members were women, a company received two points. This scoring remained the same through to 2009. In 2010, the value scoring for women board members changed to a maximum of four points if at least one-third of the directors were women; two points if $25 \%$ were women; one point if one or less than $25 \%$ but more than $0 \%$ were women; and zero points for no women directors. In order to do the analyses, without counting women on both sides of the equation and confounding the analyses, the company governance score was adjusted for the point(s) received for having women on the Board of Directors. For example, if Scotiabank received a score of 86 and had four women out of 16 board members, that score was adjusted to 84 to subtract the two points received for the presence of $25 \%$ women board members.

For purposes of this study, data from 2004, 2006, 2009, 2011, and 2012 were used to obtain a longitudinal perspective. These five points in time were documented and tabulated over the five years of data. Of the 228 companies originally listed in the 2004 corporate governance ratings, data were complete for 211 companies. Furthermore, only 
104 companies of the original 228 were still being rated in 2012. There were 244 companies rated in 2012, which indicated that 140 'new companies' were represented. Therefore, only partial data from the same companies occur in the database for a section of detailed analyses over time. As one would expect, there are many changes from year to year for specific companies which are publicly traded. New companies are created, some companies have merged, been sold, taken private, and/or are no longer listed on the S\&P/TSX composite index. Therefore, complete and continuous data were not available for all companies, and sample sizes vary for the different years.

$C S R$ ratings. $C K$ magazine publishes a list of the top 50 corporate citizens in Canada each year. Criteria for inclusion to the list are that the company must be publicly traded as of December 31 of the previous year on the TSX and/or have Canadian headquarters. The scoring system is based on environmental, social, governance, transparency, and relative core business impact indicators found in the public domain. Examples are as follows:

1 environmental waste productivity: sales (\$USD) per total waste produced in tonnes

2 social: funded status of defined-benefit pension plan benefit obligations

3 governance: existence of a link between sustainable criteria and a senior executives' compensation

4 transparency: percentage of voluntary data points (injuries) reported

5 relative core business impact: eco-social differentiation.

The first four indicators account for $85 \%$ of the score and the last indicator for $15 \%$.

Scores on Canadian companies’ $C K$ rankings over the years 2006, 2009, 2011, and 2012 were used to test the relationship between social responsibility and number of women on the board of directors. Scores previous to 2006 were not standardised out of 100, so 2004 was not used. Only a small database exists because just the top 50 companies from Canada are evaluated each year, and these are not the same companies every year. Data from $C K$ were matched to the same companies in the $G \& M$ Corporate Governance ratings. Additionally, each year, the top 100 companies worldwide are scored based on the variety of criteria related to social responsibility. For 2012, data from various industries across 22 different countries were rated in the Top 100.

CEO compensation. Information on CEO compensation in 2012 was sourced from the G\&M Report on Executive Compensation for Canada's top earners (Globe and Mail, 2012). The compensation survey included the 100 top paid CEOs in Canada for 2012. Data for base salary and bonuses were reported, along with pension, option grants, stock awards, and miscellaneous compensation given to the CEO in the previous year. Two sets of data were used in this study:

1 salary and bonus to represent pay

2 the sum of all columns to represent total compensation.

Additional data. In addition to looking at the overall data, it became important to look at the data by industry sector because different sectors may be more 'friendly' to women. Also, Canada is a resource-based economy, which heavily weights traditional male occupations (such as engineering) found in the energy and mining sectors. The S\&P/TSX identifies ten industry segments: 
1 financial services

2 mining/materials

3a consumer discretionary

3b consumer staples

4 industrials

5 healthcare

6 information technology

7 energy

8 telecommunications

9 utilities.

This classification was used for further analyses in this study, with one exception: Consumer Discretionary and Consumer Staples were coded under the same category 'Consumer' (as both related to consumer goods) to increase sample size. Given the nature of the Canadian economy, the energy and mining sectors have the largest number of firms (over 50\% of the firms rated in 2012), while utilities and telecommunications have the smallest number of firms (6-7\%). Due to the small sample sizes for the information technology, healthcare, telecommunications, and utilities sectors, they were not analysed individually.

Additional data for the total number of board members and number of women on boards were compiled from company websites and annual reports. Market cap data for 2004 and 2012 were obtained from the Globe and Mail's Report on Business magazine for the top 1,000 profitable companies (Globe and Mail, 2005, 2013).

\subsection{Independent variable}

The number of women on the boards of directors was the independent variable, categorised as follows: $0=$ no women board members; $1=$ one woman board member; $2=$ two women board members; and $3=$ three or more women on the board of directors. Women were also looked at, in relation to the total number of directors, as a percentage to allow the variation in the size of the boards to be taken into account and also to analyse the Corporate Governance ratings as a continuous variable.

\section{Results}

\subsection{Descriptive statistics for the sample}

The number of companies, by sector, and the average board size, overtime, are detailed in Table 1. As mentioned earlier, one characteristic of this Canadian database from the TSX is the overwhelming representation of the resource sector. In 2004, 37\% of the companies were in the energy and mining sectors; by 2012, their representation grew to $53 \%$ of publicly traded companies on the TSX rated by the $G \& M$ on corporate governance. These sectors also have the fewest board members, averaging about nine. 
Table 1 Change in industry concentration and board size by industry (TSX, 2004-2012)

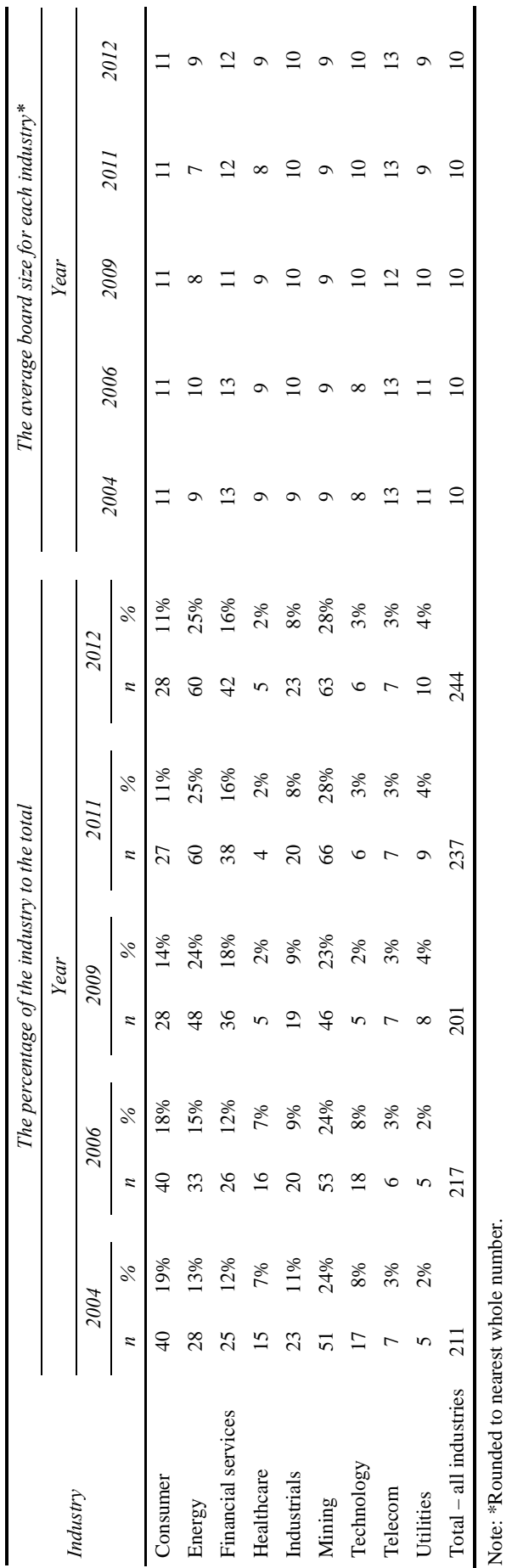


Table 2 Change in number of women board members over time by industry

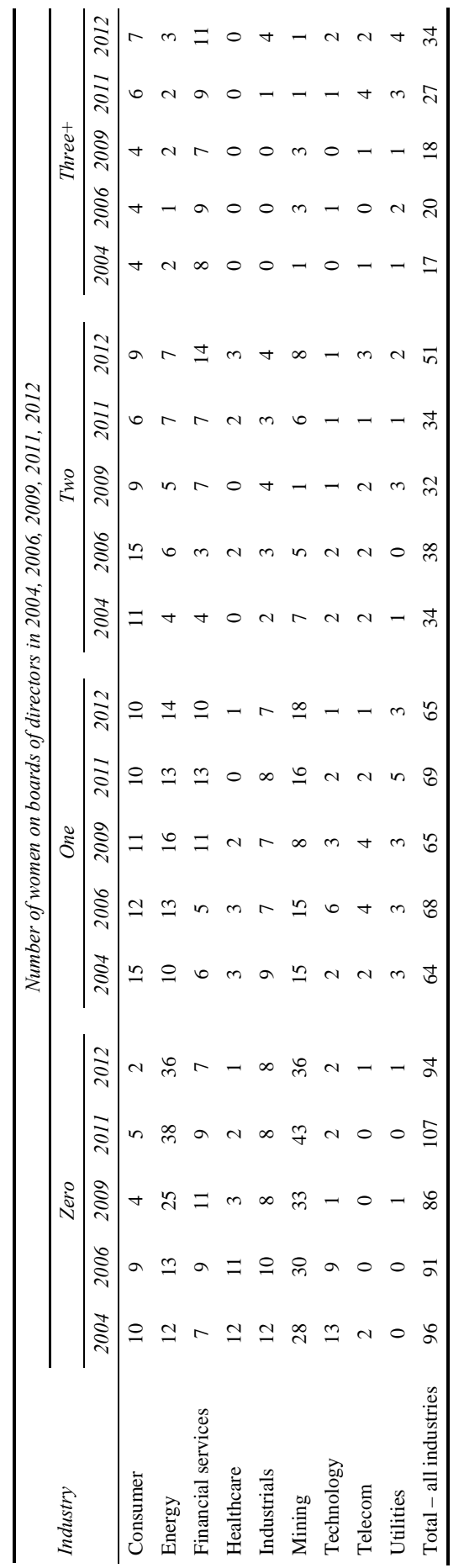


Women in the board room: one can make a difference

Table 3 Percentage of women as board members over time by industry

\begin{tabular}{lccccc}
\hline & \multicolumn{5}{c}{ Women as a \% of all board members } \\
\cline { 2 - 6 } Industry & 2004 & 2006 & 2009 & 2011 & 2012 \\
\cline { 2 - 6 } & Mean $(S D)$ & Mean $(S D)$ & Mean $(S D)$ & Mean $(S D)$ & Mean $(S D)$ \\
\hline Consumer & $11.2^{\mathrm{a}}(10.0)$ & $12.3^{\mathrm{a}}(8.3)$ & $15.1^{\mathrm{c}}(12.5)$ & $14.0^{\mathrm{a}}(11.9)$ & $17.7^{\mathrm{a}}(13.2)$ \\
Energy & $7.8^{\mathrm{b}}(8.2)$ & $7.7^{\mathrm{b}}(7.0)$ & $6.1^{\mathrm{b}}(7.2)$ & $5.4^{\mathrm{b}}(7.9)$ & $5.9^{\mathrm{b}}(8.2)$ \\
Financial services & $11.5^{\mathrm{a}}(10.1)$ & $10.1^{\mathrm{a}}(8.7)$ & $10.1^{\mathrm{a}}(8.5)$ & $12.7^{\mathrm{a}}(10.2)$ & $16.4^{\mathrm{a}}(10.6)$ \\
Healthcare & $2.0^{\mathrm{c}}(4.2)$ & $3.7^{\mathrm{b}}(6.2)$ & $4.9^{\mathrm{a}, \mathrm{b}}(6.8)$ & $10.6^{\mathrm{a}}(12.2)$ & $14.9^{\mathrm{a}}(9.7)$ \\
Industrials & $6.1^{\mathrm{b}}(6.8)$ & $6.0^{\mathrm{b}}(6.7)$ & $7.4^{\mathrm{a}, \mathrm{b}}(7.2)$ & $8.3^{\mathrm{a}, \mathrm{b}}(8.3)$ & $12.3^{\mathrm{a}}(12.4)$ \\
Mining & $5.7^{\mathrm{b}}(6.9)$ & $6.2^{\mathrm{b}}(7.7)$ & $4.3^{\mathrm{b}}(8.4)$ & $4.7^{\mathrm{b}}(7.0)$ & $6.0^{\mathrm{b}}(7.8)$ \\
Technology & $3.0^{\mathrm{c}}(5.8)$ & $7.0^{\mathrm{b}}(8.2)$ & $10.5^{\mathrm{a}, \mathrm{b}, \mathrm{c}}(8.1)$ & $12.0^{\mathrm{a}}(12.7)$ & $14.5^{\mathrm{a}}(13.2)$ \\
Telecom & $9.3^{\mathrm{a}}(7.7)$ & $10.0^{\mathrm{a}, \mathrm{b}}(2.2)$ & $13.4^{\mathrm{a}, \mathrm{c}}(7.8)$ & $20.3^{\mathrm{c}}(8.5)$ & $13.5^{\mathrm{a}}(8.4)$ \\
Utilities & $13.9^{\mathrm{a}}(6.7)$ & $15.9^{\mathrm{a}}(6.8)$ & $14.7^{\mathrm{c}}(9.7)$ & $17.2^{\mathrm{a}}(10.8)$ & $21.4^{\mathrm{a}, \mathrm{c}}(12.3)$ \\
All industries & $7.6(8.4)$ & $8.4(8.0)$ & $8.4(9.4)$ & $8.7(9.0)$ & $10.8(11.2)$ \\
\hline
\end{tabular}

Note: Industries with different superscripts (a, b, c) are significantly different at $p<.05$ level.

The number and percentage of women on boards of directors, over time and by industry, are listed in Tables 2 and 3. Notably, the energy and mining sectors have the smallest representation of women on their boards of directors, at about $6 \%$, which did not change over the eight year time period 2004-2012.

The overall average percentage of women on boards grew from about $8 \%$ in 2004 to about $11 \%$ in 2012 . There was an increase in the appointment of women directors in the following sectors: financial services (12-16\%); consumer goods (11-18\%); industrials (6-12\%); healthcare (2\%-15\%); technology (3\%-15\%); telecommunications (9-14\%); and utilities (14-21\%). Utilities had the highest representation of women on their boards in 2012 at $21 \%$, which could be attributed to government regulation of these businesses in Canada. 26\% of the financial institutions (11) had three or more women on their board and $14 \%$ of the industries in the total sample had three or more women on their boards by 2012. Overall, there was a statistically significant difference in representation of women on boards of directors across the nine Canadian industry sectors in each of the five years reported (see Table 3).

\subsection{Tests of the research questions}

\subsubsection{RQ1: Does having more women on the board of directors lead to more effective corporate governance?}

Overall and consistently over time, companies with more women on their boards of directors scored significantly higher on corporate governance (see Table 4). More specifically, companies with three or more women on boards always had the highest governance scores. However, boards with only one woman member scored significantly higher on the rankings in each time period, with the exception of 2006. Generally, post-hoc tests of the data showed a statistically significant difference in corporate governance scores between zero women and one woman; no difference, between one and two women; and a significantly higher score for companies with three or more women. This finding is consistent over time. Also, it is noteworthy that more than $50 \%$ of the companies in 2012 are different from 2004. 
Table $4 \quad G \& M$ corporate governance scores by number of women board members over time

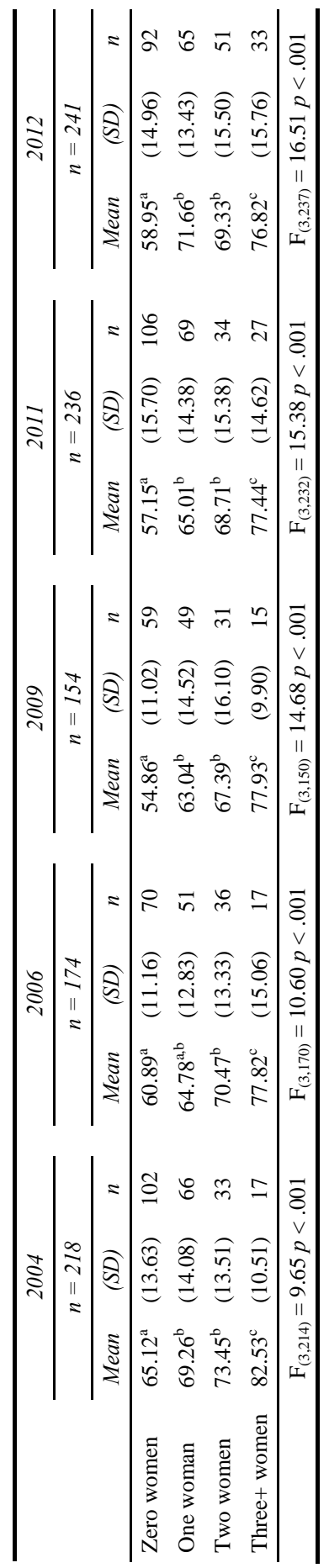


Table $5 \quad G \& M$ corporate governance scores for 2012 by industry related to number of women board members

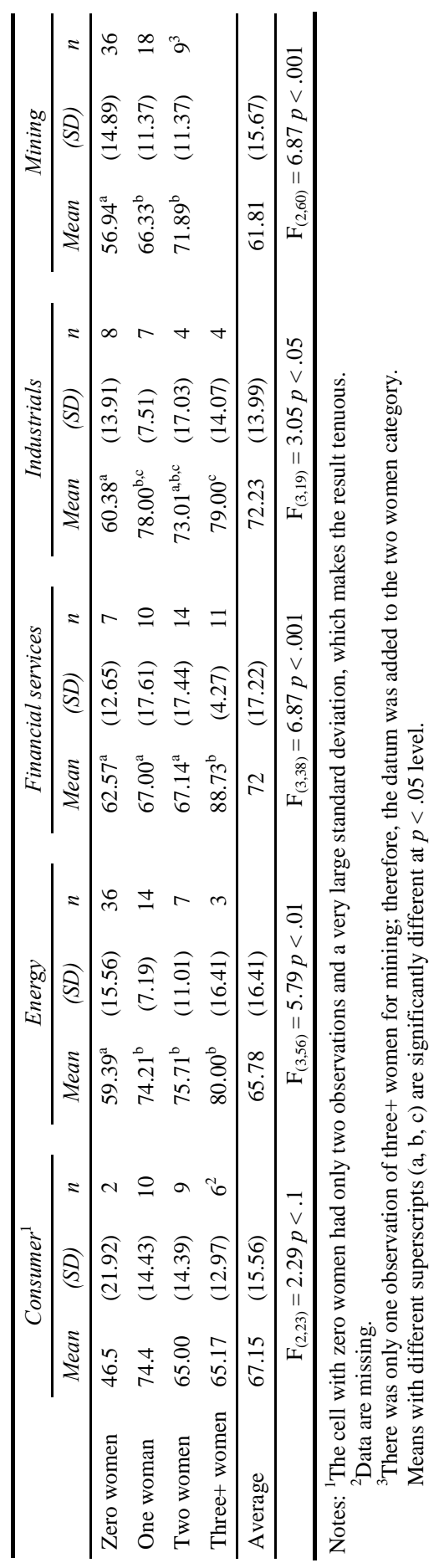


Because previous research found larger companies tend to have more women on their boards of directors (e.g., Adams and Ferreira, 2009), the analyses were rerun for 2004 and 2012 using market cap as a covariate. For 2004, market cap data for 197 of the 218 companies were used (Globe and Mail, 2005). When the 2004 data were reanalysed, statistically significant effects for market cap $\left(\mathrm{F}_{(1,192)}=19.06, p<.001\right)$ and still a significant effect for number of women on boards were found $\left(\mathrm{F}_{(3,192)}=4.38, p<.005\right.$; adjusted $R^{2}=.19$ ). The 2012 data were then reanalysed for 203 of the original 241 companies; again, there were statistically significant effects for market cap $\left(\mathrm{F}_{(1,198)}=19.25, p<.001\right)$ and number of women on boards $\left(\mathrm{F}_{(3,198)}=7.8, p<.001\right.$; adjusted $R^{2}=.22$ ). In summary, there is a relationship between larger companies and higher scores on corporate governance. Further, after accounting for the size of the company, companies with more women on their boards scored higher on corporate governance.

The next step in the analysis was to determine if the positive finding for corporate governance scores related to a greater number of women on boards of directors varies by the nature of the industry. Industry sectors with an adequate number of observations for 2012 were analysed by number of women on their boards and their relation to corporate governance scores: consumer $(n=27)$; energy $(n=60)$; financial services $(n=42)$; industrials $(n=23)$; and mining $(n=55)$ (see Table 5). While the cell sizes are small, the 'three women to make a difference' rule was found for the financial services sector only. Financial institutions which had zero, one, or two women on their boards scored about the same on corporate governance; only those with three or more women scored higher. In the energy, industrials, and mining sectors, the corporate governance scores were higher, on average, only when there was one woman on the board of directors. In the consumer sector, only two observations had no women and hence no definitive conclusion could be drawn due to the large variations and instability of the statistical test. In addition to the small sample size, it is worth noting the dwindling supply of large TSX consumer-based industries in Canada (40 companies down to 28) over the eight year span of this study.

One last investigation involved the companies that were present in the initial dataset from 2004 and then again in the 2012 ratings. Only 104 companies of the original 218 in 2004 were rated after only eight years later. Cross-tabulation revealed a statistically significant relationship between the number of companies and the number of women on boards of directors at the $p<.1$ level (see Table 6).

Table 6 Relationship between stability (number of TSX companies over time) and the number of women on boards

\begin{tabular}{lcccc}
\hline & \multicolumn{3}{c}{ Number of companies } & \\
\cline { 2 - 4 } & 2004 & 2012 & Total & \\
\hline Zero women & 102 & 35 & 137 & $\chi^{2}=6.55, p<.1 ; \mathrm{df}=3$ \\
One woman & 66 & 33 & 99 & \\
Two women & 33 & 23 & 56 & \\
Three+ women & 17 & 13 & 30 & \\
\hline Total & 218 & 104 & & \\
\hline
\end{tabular}


Table $7 \quad C K$ corporate social responsibility ratings by number of women on boards over time*

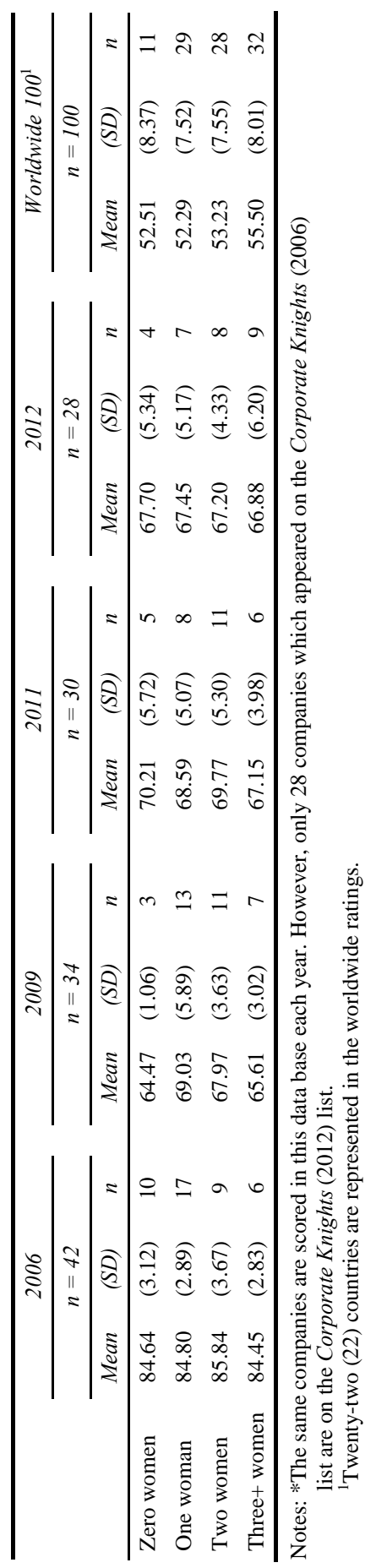




\subsubsection{RQ2: Does having more women on the board lead the company to be more socially responsible?}

Using the same companies over time, there was no relationship between CSR scores, as measured and reported by $C K$, and the number of women on the boards (see Table 7). Note that although the cell sizes are small, so are the standard deviations; hence, there is some confidence in the data. However, because these findings seemed tenuous due to the small sample size, the 100 worldwide companies rated by $C K$ for 2012 were analysed (Hamilton, 2013). The same results were found on a world-wide basis: there was no relationship between the $C K C S R$ ratings and the number of women on the boards of directors (see Table 7).

\subsubsection{RQ3: Do companies with more women on their board award the CEO higher compensation?}

Using the Globe and Mail (2012) executive compensation data, ANOVA was applied with the number of women on the boardmeasured by a categorical variable $(0,1,2$ or $3+)$ against the compensation received in the form of salary and bonuses (Table eight). There were no statistically significant results $\left(\mathrm{F}_{(3,88)}=1.75\right.$, n.s.). Subsequently, a regression of salary and bonus as the dependent variable and the number of women as a percentage of the board seats as the independent variable was run; again, a statistically significant relationship was not found. This analysis was then repeated using market cap as a covariate, which revealed a statistically significant relationship between CEO salaries and bonuses and market cap ( $\beta=.22, t=1.99, p<.05$ ), but no relationship between the percentage of women on the board of directors and CEO salaries and bonuses (adjusted $\left.R^{2}=.03\right)$.

Table 8 CEOs subtotal salary (base salary and bonus) and total compensation by number of women on the board in 2012

\begin{tabular}{|c|c|c|c|c|c|c|}
\hline & \multicolumn{3}{|c|}{ CEO subtotal salary } & \multicolumn{3}{|c|}{ CEO total compensation } \\
\hline & \multicolumn{3}{|c|}{$N=92$} & \multicolumn{3}{|c|}{$N=92$} \\
\hline & Mean & $(S D)$ & $n$ & Mean & $(S D)$ & $n$ \\
\hline Zero women & $\$ 1,730,148^{\mathrm{b}}$ & $(1,337,212)$ & 21 & $\$ 4,166,516^{\mathrm{b}, \mathrm{c}}$ & $(2,993,327)$ & 22 \\
\hline One woman & $\$ 2,729,457$ & $(2,816,497)$ & 25 & $\$ 6,022,430$ & $(3,618,041)$ & 25 \\
\hline Two women & $\$ 2,924,029^{a}$ & $(1,620,912)$ & 24 & $\$ 6,575,679^{a}$ & $(3,312,449)$ & 23 \\
\hline Three+ women & $\$ 2,357,172$ & $(998,313)$ & 22 & $\$ 6,779,553^{a}$ & $(3,140,235)$ & 22 \\
\hline
\end{tabular}

Notes: Means with different superscripts (a, b, c) are significantly different at $p<.05$ level.

Note that this data is aggregated across all industries.

Next, the relationship between the number of women on boards $\left(0,1,2,3^{+}\right)$and total CEO compensation (including all pension and stock options in addition to salary benefits) was examined. There was a statistically significant effect: more women on boards led to higher total CEO compensation $\left(\mathrm{F}_{(3,88)}=2.9, p<.05\right)$. However, when market cap was inserted as a covariate, the results then showed a statistically significant effect for market cap $\left(\mathrm{F}_{(1,80)}=26.96, p<.001\right)$, but no effect for number of women. The data for total CEO compensation was then reanalysed using the percentage of women on the board as the independent variable and market cap as a covariate. The results showed the percentage of 
women on boards was not related to total CEO compensation, but market cap was again statistically significantly $\left(\beta=.31, t=2.9, p<.01\right.$; adjusted $\left.R^{2}=.10\right)$. In conclusion, no effects were found for the relationship between the number or percentage of number of women at the board table of Canadian companies and CEO compensation after accounting for the size of the company. The companies were not analysed by industry sector due to small sample sizes.

\section{Discussion and summary}

Clearly, the number and percentage of women on boards of directors in Canada over many sectors (other than energy and mining) have increased over the years. This increase may have occurred because Canada's Crown corporations (utilities), as well as banking and telecommunications companies, are governed by the federal Employment Equity Act, which encourages preferential hiring for diversity. Quebec legislated gender balance on the boards of their Crown corporations in 2006; they have achieved this goal. Overall, this empirical study showed an overwhelmingly positive relationship between more women on Canadian boards and higher corporate governance scores. There is no conclusive evidence, however, that a company needs at least three or more women to improve governance.

While companies with the most women scored the highest on corporate governance, an important finding of this study is that there is significant improvement with one woman over none on boards, especially in male-dominated industries, such as energy and mining. To call for quotas of three or more women to be on boards of directors of these industries, for which the total number of board seats averages about nine, is perhaps asking too much. At this point in time, one woman on these boards may be all it takes to provide a better governed and maybe an even more stable company. Further, to ask for legislation to support quotas of three women, especially on small boards of six to nine members, maybe met with a door in face. The findings of this study suggest that strategically, it is better to get a foot in the door of male-dominated boards with one woman who understands the business. In short, this study provides support for nudging in with one woman on a board, rather than barging in with three women.

The ability to be effective, while the only woman on the board, is supported by previous qualitative studies (e.g., Lamkin Broome et al., 2011). A lone woman on the board does not mean she is not part of the organisation, nor excluded from the dominate culture. This is demonstrated by a quote from a lone woman board member when asked, 'What does it feel like to be the only woman on the board?' She replied,

\footnotetext{
"Well I don’t really look at myself as the only woman on the board. I just feel like I am a board member. They seem to have accepted me well and we enjoy each other and that: I don't usually think about being the only one. I mean I don't think about diversity.” [Lamkin Broome et al., (2011), p.1065]
}

Thus, this empirical study supports Lamkin Broome et al.’s (2011) finding that some women directors viewed themselves as path breakers. Lone women were said to exhibit a certain pride in being a highly qualified corporate director. They were accustomed to their outsider status and needed no additional support from the presence of members of their own gender group. Recalling Kanter's (1977b) original statement about tokenism, this study also supports the premise that 'tokens' or individual women do improve the 
governance of a corporation, perhaps because they are with their own social category and identify with the group.

The other interesting finding of the present study is the weak (but positive) relationship between the same 104 companies rated in the two time periods (2004 and 2012) and the number of women at the board table. This finding brings to mind the question, "Does more effective governance lead the company to greater stability or more resistant to takeovers?" There was a shift in the number of companies in particular industries rated for corporate governance by the $G \& M$, over a rather short time period (eight years). Less than $50 \%$ of the original companies were still among the companies being rated, although the number of resource-based companies nearly doubled. The time frame also included the financial crisis of 2008, which led to much reorganisation in world economies. Maybe women at the board table will help keep industries and corporations strong if indeed more women lead to more stable companies over time.

No relationships were found between CSR, as measured by Corporate Knights (2006, 2013), and the number of women on boards for the same Canadian companies. Data for the largest global 100 companies for 2012 also showed no differences in their CSR ratings among companies that have zero, one, two, or three plus women on their boards. Reasons for the disparate findings for corporate governance and CSR may be due to the amalgamation of the data over all industries in the $C K$ database. Also, the $C K 100$ companies represented 22 different companies across various industry sectors. Variability due to country, culture, and industry may be at play.

The number of women on the board was also not related to CEO compensation, either for pay (salary and bonuses) or total compensation, although CEO pay and compensation was strongly related to the size of the company. A larger sample within one industry is warranted to further study the relationship between CEO compensation and the number of women on boards. The link to other quantitative outcomes of firm performance is also an area for further study.

\subsection{Limitations}

When there are conflicting findings, Lawrence (1997) states that the issue is one of theory; one of data; or one of analyses. The theory that women are well-suited to be board members is indeed strong (Arfken et al., 2004). Women are well-educated, contributing members of organisations, and effective managers. They are also consumers who buy and have much decision making power in the marketplace. However, not all women are alike, just as not all men are alike. Boards should be comprised of people who have the best understanding of the business and the best concerns for a viable, profitable organisation which treats its employees and customers to the highest standards. Lawrence (1997) points out that the simple gender variable does not shed light on the complexities of the issue, such as qualifications and economic environments. However, this study shows that women are making a difference, even when they are the lone voice.

One must accept the soundness of the methodology and measures used by the $G \& M$ and $C K$ to create their published data. Both publications are extremely transparent in their questions and analyses. Board size, number of women board members, CEO compensation, Corporate Governance scores, CSR scores, and market cap came from different databases, and were compiled carefully. Measures must be agreed upon to compare studies accurately. Data must be based on standardised measures that 'fit' every country and industry. Women can be counted, but finding acceptable measures for the 
dependent variables, which will be widely used and accepted, is much more difficult. Some researchers create their own dependent measures (e.g., Huse et al., 2009), but rarely are the same questions used to measure the same concept in different research studies. Standardised measures of the 'effectiveness of women on boards' need to be developed.

With respect to the methods of analyses, simple analyses are easy to understand, but yield only correlations, not causations. The best approach would be to study long-standing companies and do longitudinal studies as more women are appointed to boards. But, how many variables need to be accounted for in the analyses and how large a sample is needed to have confidence in the findings?

There may also be differences in cultural values due to country-of-origin or industry. Does it make sense to compare the USA with Norway or Canada or Australia? Canada, Norway, and Australia together do not make up the population and economic power of the USA. Additionally, countries differ in their concentration of industries and the type of governmental industry regulations that govern publicly traded companies. It could be revealing to compare industries across countries, rather than different industries within individual countries.

Morgan Stanley is not the first company to create an investment portfolio around companies committed to representation of women at the board table. In 2009, it was announced Naissance Capital out of Switzerland would create the 'Women's Leadership Fund' and invest in companies that have women on their boards of directors (Werdiger, 2009). The eight directors of the fund included seven women, including two former Prime Ministers (from Canada and New Zealand). To date, this fund has not been able to raise a critical amount of capital to become an actively managed fund. The founder of the fund expressed the frustration that women themselves have not stepped up to the plate to invest (minimum contribution $\$ 100,000$ ), nor have any major pension funds (Telephone interview with James Breiding, Naissance Capital, Switzerland, October 21, 2013). It will be interesting to see if Morgan Stanley's 'Parity Portfolio' fund will have the same problem in securing a critical mass of investors. The minimum contribution is $\$ 250,000$. It is ironic that Morgan Stanley itself is not qualified to be part of the fund because they have only two women board members out of 14 seats.

The other issue that became evident while doing this research was that the same women are board members for multiple companies. In 2006, Norway led the way by legislating that $40 \%$ of board directors had to be women; they achieved that goal by 2008 . The results of the quotas show that a few women are holding many directorships, with one woman on eight different boards by 2009 and $61.4 \%$ of the women on the boards holding at least three different directorships (Seierstad and Opsahl, 2011). So, there is a dramatic increase in multiple board appointments for the same person. Norway has more boards with women, but not necessarily more total women in the mix.A similar situation appears in Canada without the quota ruling (Greenwood, 2013). There is one woman with seven directorships; three, with six board seats; five, with five board seats; and 23, with four board seats.

Korn/Ferry suggests that the maximum numbers of boards a person can adequately handle are three to four, with one or two additional appointments for persons holding CEO positions (O’Callaghan et al., 2006). So, why are the same women appointed to more than three boards? A common recruitment assertion is that "when you interview for a job, it is all about your qualifications, but when you interview for a board it is about how compatible you can be”. The key is said to be in signalling that you can ask the right 
questions (Reier, 2008). Or maybe it is not asking the wrong questions. Future research that documents the reasons for appointing women to multiple boards could be very insightful.

Canada is a country that values equality, yet experienced women are few relative to the many energy and mining board seats that are increasing. Further, the lowest corporate governance scores were seen for these industries, and they had the fewest women on boards. As this study showed, adding one woman to the board is predicted to improve corporate governance, that is, it takes only one woman in the boardroom to make a difference.

\section{Acknowledgements}

The author is indebted to Rosemary Polegato for her help in the preparation of this manuscript; and to Carolyn Egri and Oliver Schilke for their feedback on a previous draft.

\section{References}

Adams, R.B. and Ferreira, D. (2009) 'Women in the boardroom and their impact on governance and performance', Journal of Financial Economics, Vol. 94, No. 2, pp.291-309.

Adams, R.B. and Funk, P. (2012) 'Beyond the glass ceiling: does gender matter?', Journal of Management Science, Vol. 58, No. 2, pp.219-235.

Arfken, D.E., Bellar, S.E. and Helms, M.M. (2004) 'The ultimate glass ceiling revisited: the presence of women on corporate boards', Journal of Business Ethics, Vol. 50, pp.177-186.

Asch, S.E. (1955) 'Opinions and social pressure', Scientific American, November, Vol. 193, pp.31-35.

Bart, C. and McQueen, G. (2013) 'Why women make better directors', International Journal of Business Governance and Ethics, Vol. 8, No. 1, pp.93-99.

Bear, S., Rahman, N. and Post, C. (2010) 'The impact of board diversity and gender composition on corporate social responsibility and firm reputation', Journal of Business Ethics, Vol. 97, No. 2, pp.207-221.

Bond, R. (2005) 'Group size and conformity’, Group Processes and Intergroup Relations, Vol. 8, No. 4, pp.331-354.

Canadian Coalition (2011) 'Brief to Senate Committee on banking, trade and commerce', Canadian Coalition for Good Governance: The Voice of the Shareholder, Submitted 31 January 2011.

Committee for Economic Development (CED) (2012) Fulfilling the Promise: How More Women on Corporate Boards Would Make America and American Companies More Competitive, Washington, DC.

Corporate Knights (2006) 'Corporate Knights best 50 corporate citizens rankings', Vol. 5.1, pp.24-25.

Corporate Knights (2013) 'The Global 100', Vol. 11, No. 4, pp.33-38.

Daily, C.M., Certo, S.T. and Dalton, D.R. (1999) 'A decade of corporate women: some progress in the boardroom, none in the executive suite', Strategic Management Journal, Vol. 20, No. 1, pp.93-99.

Davis, L. (2011) Women on Boards, report to the UK Secretary for State for Business, Innovation Skills and the Minister for Women and Equalities, February. 
European Commission Directorate General for Justice (2012) Women in Economic Decision Making Progress Report: A Europe 2010 Initiative, Luxembourg Publications Office of the European Union.

Fernandez-Feijoo, B., Romero, S. and Ruiz, S. (2012) 'Does board gender composition affect corporate social responsibility reporting?', International Journal of Business and Social Science, Vol. 3, No. 1, pp.31-38.

Globe and Mail (2005) '1000 rankings by profit', Report on Business, pp.44-74.

Globe and Mail (2012) 'Executive compensation: rankings for Canada’s top earners', 8 June [online] http://www.theglobeandmail.com/report-on-business/careers/management/ executive-compensation/executive-compensation-rankings-for-canadas-topearners/article4243534/ (accessed 27 May 2013).

Globe and Mail (2013) ‘Top 1000: our annual report of Canada’s most profitable companies', Report on Business, July-August, pp.54-68.

Greenwood, J. (2013) 'The rare commodity on Canadian boards - women', The Financial Post, 12 October [online] http:business.finacialpost.com/2013/10/12 (accessed 12 October).

Gregory-Smith, I., Main, B.G.M. and O’Reilly, C.A. (2014) 'Appointments, pay and performance in UK boardrooms by gender', The Economic Journal, Special Issue, Vol. 124, No. 574, pp.F109-F128, doi: 10.1111/ecoj.12102.

Hamilton, T. (2013) 'Super company’, Corporate Knights, pp.28-45.

Hillman, A.J. and Cannella, A.A. Jr. (2007) 'Organizational predictors of women on corporate boards’, Academy of Management Journal, Vol. 50, No. 4, pp.941-952.

Huse, M., Nielsen, S.T. and Hagen, I.M. (2009) 'Women and employee-elected board members and their contributions to board controlled tasks', Journal of Business Ethics, Vol. 89, No. 4, pp.581-597.

Joecks, J., Pull, K. and Vetter, K. (2013) 'Gender diversity in the boardroom and firm performance: what exactly constitutes a 'critical mass", Journal of Business Ethics, Vol. 118, No. 1, pp.61-72.

Kang, H., Cheng, M. and Gray, S.J. (2007) 'Corporate governance and board composition: diversity and independence of Australian boards', Corporate Governance, Vol. 15, No. 2, pp.194-207.

Kanter, R.M. (1977a) Men and Women of the Corporation, Basic Books, New York.

Kanter, R.M. (1977b) 'Some effects of proportions on group life: Skewed sex ratios and responses to token women', The American Journal of Sociology, Vol. 82, No. 5, pp.965-990.

Konrad, A.M., Kramer, V. and Erkut, S. (2008) 'Critical mass: the impact of three or more women on corporate boards', Organizational Dynamics, Vol. 47, No. 2, pp.145-164.

Lamkin Broome, L., Conley, J.M. and Krawiec, K.D. (2011) 'Does critical mass matter? Views from the boardroom', Seattle University Law Review, Vol. 34, No. 4, pp.1049-1080.

Lawrence, B.S. (1997) 'The black box of organizational demography', Organizational Science, Vol. 8, No. 1, pp.1-22.

Luckerath-Rovers, M. (2013) 'Women on boards and firm performance', Journal of Management and Governance, Vol. 17, No. 2, pp.491-509

McFarland, J. (2013a) 'Members named to panel to boost women in boardrooms', The Globe and Mail, 6 April, p.B4.

McFarland, J. (2013b) 'Teachers pushes OSC to require three women on every board', The Globe and Mail, 8 October, p.B4.

Nelson, J. (2013) 'Parity portfolio places bets on women', Globe and Mail, 21 March, p.B3.

Norris, J.C. (2012) 'Women on boards: review and outlook', The Conference Board, May [online] https://www.conference-board.org/ retrievefile.cfm?filename=TCB-DN-V4N9-12.pdf\&type=subsite (accessed 20 October 2012).

O’Callaghan, P. et al. (2006), Gender Diversity on Corporate Boards, report in partnership with Korn/Ferry Associates. 
O’Reilly, C.A. III and Main, B.G.M. (2012) Women in the Boardroom: Symbols or Substance?, Research paper, No. 2098, Stanford Graduate School of Business.

Reier, S. (2008) 'Women take their place on corporate boards', International Herald Tribune, 21 March [online] http://www.iht.com/bin id=11318955 (accessed 3 April 2008).

Rhinehart, M., Vitale, M.B. and White, M. (2013) 'Board diversity: the power of three', NACD Directorship [online] http://www.directorship.com/board-diversity-the-power-of-three/ (accessed 28 March 2013).

Rose, C. (2007) 'Does female board representation influence firm performance?: The Danish evidence', Corporate Governance, Vol. 15, No. 2, pp.404-413.

Seierstad, C. and Opsahl, T. (2011) 'For the few not the many?: The effects of affirmative action on presence, prominence, and social capital of women directors in Norway', Scandinavian Journal of Management, Vol. 27, No. 1, pp.44-54.

Strategic Direction (2013) 'Board diversity - math or merit? Should gender equity depend on quotas?', Vol. 29, No. 2, pp.6-9.

Terjesen, S. and Singh, V. (2008) 'Female presence on corporate boards: a multi-country study of environmental context', Journal of Business Ethics, Vol. 83, No. 1, pp.55-63.

The Economist (2013) 'More women on boards', Print edition 23 November [online] http://www.economist.com/news/business/21590372-more-women-boards/print (accessed 24 November 2013)

The Globe and Mail (2005) 'Corporate social responsibility ranking report on business', pp.40-41.

The Globe and Mail (2012) Corporate Governance Board Games 2012: Methodology [online] http://www.theglobeandmail.com/report-on-business/careers/

management/board-games-2012/board-games-2012-methodology/article5647746/?page=all (downloaded) (accessed 22 March 2013).

Torchia, M., Calabro, A. and Huse, M. (2011) 'Women directors on corporate boards: from tokenism to critical mass', Journal of Business Ethics, Vol. 102, No. 2, pp.299-317.

Werdiger, J. (2009) 'Fund plans to invest in companies with women as directors', The New York Times, 27 October [online] http://www.nytimes.com/2009/1027/business/global /27fund.html (accessed 30 March 2013). 


\section{Appendix}

Globe and Mail scoring system for 2012 board games

1 Board composition (31 marks out of 100):

This section is comprised of 11 questions pertaining to independence, roles of board members, seats on multiple boards, presence of women, and meetings with management. For example, 'What percentage of the company's directors is fully independent?' The independence refers to directors who are not management, relatives of the management, former members of the management, or people whose firms do business with the company. The company gets four marks for boards which are at least two-thirds independent, two marks if $50 \%$ of the members are independent, and zero if there is a majority of related directors on the board.

2 Shareholding and compensation (26 out of 100):

Fourteen questions are asked which relate to ownership of shares in the company, loan practices, compensation, and disclosure of compensation. For example, Q.14a: 'How well does the company disclose the compensation policies it applies when deciding CEO bonuses? Does it provide a percentage of weighting of the factors that are considered in determining the bonuses?' One mark, if yes; zero marks, if no.

3 Shareholder rights issues (31 out of 100):

Thirteen questions pertaining to the specific voting practices of shareholders, dilution of stock options, option plan features, performance hurdles for deferred shares and non-voting shares make up these 31points.

4 Disclosure issues (12 out of 100):

There are ten questions with regard to relation of directors, biographies, attendance of board members at meetings, and other board member information and behaviour. For example, 'Does the company disclose directors' ages?' One mark is assigned if yes; zero marks, if no.

Source: Globe and Mail (2012) 